\title{
EDITORIALS
}

\section{Welcome, Environmentalists !}

Come years ago we drafted an editorial entitled 'Can the Ecologists Save the World?', which attempted to answer Ojust that question-at least in ultimate prospect. Being sadly dissatisfied with our effort as well as disenchanted with some aspects of the 'popular' movement which had engendered it (which, inter alia, did not seem to know where it was going or even what to aim at), we did not seek comments on that editorial or ever use it. Indeed we forgot about it until we came upon it the other day when engaged in the tiresome but recurrently necessary task of throwing away old papers. It did, however, make the useful if evident point that there are two kinds of ecologists in our modern world, namely the suitably qualified devotees of the science of ecology, which deals mainly with the relationships of living organisms with their environment (including one another) and hence is largely a biological science that can now claim to be more than a century old, and what may be called the 'popular ecologists', stemming from an activist movement that started on some American campuses in the 1960s.

The abortive editorial concluded that, for enlightened decision-making and timely action, each of the above two groups clearly needs the other. Thus the scientists need the support of the activists to get done many things which they know should be done, while the activists need the best possible scientific advice and concomitant guidance before venturing forth on their otherwise often futile or even disruptive missions. Indeed it was the conclusion of a later editorial, which we did venture to use (Environmental Conservation, Vol. 5, No. 1, page 2, Spring 1978), that 'the sooner they can get together and work in unison, the better will be the chances for Man's and Nature's survival'.

When we referred above to our disenchantment with some aspects of the "popular ecologists" movement which 'did not seem to know where it was going', we were thinking of our experience in 1969 when, as chairman of the symposium entitled 'Conservation and Environment Concerns' at the XIth International Botanical Congress, in Seattle, Washington, we put it to the several-hundreds-strong gathering of delegates and others that human population-pressures seemed destined to engender by far the greatest problems with which our world has ever been confronted. This prototype resolution, of the actual wording of which we have no record, was approved nemine contradicente. Indeed, no one raised a peep in protest or even question. Thereafter we were asked by a group of mildly 'hippy' students from Berkeley, California ('where it all started', I was told), to help them in drafting a resolution to the same general effect, and to visit them later on their campus. These things we did, being duly impressed by the students' sincerity, and feeling that they had some good points although lacking any clear direction. They told us in Berkeley that they had collected two large volumes of signatures in support of our resolution about human population-pressures, including those of many leading participants of the Congress in Seattle, and asked us if we thought, being resident in Switzerland, it would be possible to arrange for their volumes to be housed in the Library of the Office of the United Nations in Geneva. Knowing the Librarian we said we thought it should be possible, as nothing explosive or unduly partisan was involved. But on our return home, when we were about to see whether the students' request could be granted, we received a message from their leader in Berkeley to the effect that they had had some misgivings about those signatures and had burned the lot!

In the latest French presidential election, when the party advocating due concern for the local environment made their point successfully by obtaining a quite substantial proportion (amounting to some millions) of the votes, we noticed that much of the verbiage was of 'environnement' and 'environnementalistes' rather than 'écologie' and 'écologistes', though admittedly one of the candidates, who came to see us together with his wife, still referred constantly to the 'Partie écologique'. And now that our new sister journal, dealing mainly with the higher levels of environmental education, is being called The Environmentalist, and we have contributed to its initial issue a guest 'Open Letter' entitled 'Welcome to The Environmentalist', and have moreover come to calling ourselves 'environmentalist' rather than 'ecologist', we wonder whether the former is not the better term to employ for those of us who are duly concerned (even if not always academically qualified), leaving for ecologists the science that is becoming more and more exact - and, for many former adherents, obscure-nowadays.

Anyhow, that is our present suggestion for the solution of the problem of Ecologists versus 'Ecologists' (or 'neoecologists'), with the recommendation that the so-to-be-styled environmentalists, who comprise the main core of the environmental movement, should include the more enlightened and sensible among the neo-ecologists. The spheres of interest and influence of environmentalists could accordingly be termed 'environmentalism', whose great objective should be an eternally sustained and ever-improving global environment of (and for) Man and Nature.

N.P.

\section{Stressing Pollution}

$\mathrm{H}_{8}$ aving repeatedly been asked to provide some definition and pointers for the environmental movement in its groping for cohesion, direction, and adequate support, we attempted an editorial on it in our latest issue, before going on to lament the passing of a friend such as even an editor is allowed to mention when he had been a leader in fostering a vital movement. Moreover, in the last several issues of our Journal, we have tried to comply with another chronic request - to stress topics of particular importance or urgency in particular issues without making the latter 'special' ones devoted to individual topics (such as would need a whole costly staff to carry through effectively).

Thus in our last five issues, while striving to offer some leadership from our own thought-processes projected for the hoped-for benefit of the environmental movement, we have stressed (1) the plight of the remaining tropical moist forests and the necessity (and some possible means) of saving them for posterity, (2) environmental education and 
the need for global awareness towards preserving The Biosphere, (3) the elimination of smallpox as a killing disease and widespread scourge until recently in Man's environment, (4) proposing the World Decade of The Biosphere, 198292, with some ideas for its guidance, and (5) concern for the environmental movement and its dire need of support - not only publicly and financially but also practically through such devices as environmental impact assessment and low-impact technology.

Now it seems time to stress the avoidance of pollution as a major imperative for the environmental movement and increasingly for mankind as a whole. Here once again we surely need to prevent a scourge by tackling it at the source rather than treating the symptoms when they have emerged and, all too often, done their damage. For such preemergence recognition and appropriate action a basic need is proper education - to be duly aware of dangers of and from pollution, recognize its symptoms and effects in the circumstances concerned, and take action in good time to prevent it or at least avoid its worst consequences.

We have not worried so much about environmental pollution since encouraging, more than a decade ago, the establishment of a journal of that name (as a hive-off from our own former Journal, Biological Conservation) and finding for it an Editor who has been so skilful and successful as to develop it into two series, namely A: Ecological and Biological, and B: Chemical and Physical.

But now, having just read the proofs of one of the first volumes in our new series of Environmental Monographs \& Symposia (see the announcement on page 178 of our Autumn issue last year), entitled Stress Effects on Natural Ecosystems, and realizing the vast importance of that topic which is widely concerned with various kinds and degrees of pollution, we feel we should return to emphasize this latter subject in our present issue. Accordingly we plan to include in it at least four papers on different aspects of pollution and their effects - on streams in Hong Kong, on a tidal inlet in eastern North America, and on terrestrial and lacustrine ecosystems in India. In addition, there will be some other papers and short communications in this issue and the next which will be at least partly pollutional in emphasis or context, probably adding at least one further research paper and, in due course, an expert survey one on the vital topic of the effect of chlorinated hydrocarbon pollutants (such as DDT and PCBs) on marine phytoplankton.

\section{Our Advisory Editors and Foundation Board: Updatings}

An important factor in keeping up standards, maintaining scientific integrity, and offering leadership in our columns, is the support of our distinguished panel (not 'board', as it never actually meets) of Advisory Editors. These men and women, scattered practically throughout the world, are invariably outstanding and usually leaders in their specialist fields; between them they should cover all major aspects and areas of environmentalists' endeavour. They vary greatly in their indications of activity in our direction, but, at the very least, respond to requests for advice, refereeing of papers, and other chronic needs; and of course they are always welcome as visitors in our home and headquarters near to Geneva's international airport.

Being nearly 50-strong, our panel of Advisory Editors naturally undergoes some changes from time-to-time, the most recent ones being of Dr Lee M. Talbot, DirectorGeneral of IUCN and responsible for the collaboration of that leading organization, in the place of his predecessor Dr David A. Munro; of Professor Donovan P. Kelly, Chairman of the Department of Environmental Sciences in the University of Warwick, Coventry, England, vice Professor René Dubos, concerned with Microbiological Implications; and of Sir John Adams, formerly DirectorGeneral of CERN, Meyrin, Switzerland, for Physics. Sir John took the place on our panel of Dr Amasa S. Bishop after the latter retired last year from the Directorship of the Environment and Human Settlements Division of the UN Economic Commission for Europe, though to our joy he (Dr Bishop) is remaining in our vicinity and is now resuming as Advisory Editor in matters pertaining to Energy, concerning which he is an eminent consultant. A most welcome addition is Provost F. Kenneth Hare, of Trinity College, University of Toronto, Canada, for Climatic Variation, and another, on behalf of our collaborator $W E R C$, is their Executive Officer David HughesEvans. Meanwhile Dr Donald F. McMichael, despite being now Secretary of the Department of Home Affairs and Environment of the Government of Australia, in Can- berra City, has recently confirmed his continuation of responsibility for Australasia.

In part to make room for the above additions (though we have never quite filled our contracted allowance of 50 Advisory Editors who receive 'free subscriptions' of our Journal), we have suspended, as disappointingly unproductive and latterly vacant, the 'chairs' of Evolutionary Ecology and Human Reactions - but not that of Ecosystems Research, which has become vacant through the retirement of Professor Heinz Ellenberg, but which it is hoped to fill very soon.

It should be added that Dr Talbot has also taken the place of Dr Munro on the Governing Board of the Foundation for Environmental Conservation, of which Provost Hare is Honorary Secretary and our office colleague Miss Carole A. Trangmar-Palmer the Deputy Secretary. The Foundation is a Swiss-based, tax-free and non-profit non-governmental organization (NGO) that owns this Journal and also sponsors the International Conferences on Environmental Future, the series Environmental Monographs \& Symposia, and other activities on behalf of Man's and Nature's environment.

Conforming to our 'law' that, the smaller an organization is, the more effective will be its use of its resources, The Foundation for Environmental Conservation has been commended as among the most economical means of entering almost any sort of environmental service, in that any ad hoc contribution or grant that it receives goes wholly to the stated purpose, without any deduction for overheads or unspecified services (which we supply ourselves). Much the same economy of use applies to 'open' grants and donations, except that their use is determined by the Governing Board of the Foundation - whose activities are perpetually surveyed under the auspices of the Council of State of the Republic and Canton of Geneva and supervized by the Swiss Federal Department of the Interior in Berne. 